\title{
Mundane Myths: Heritage and the Politics of the Photographic Cliché
}

This paper considers the impact of photographic clichés on the management, conceptualisation and experience of heritage. Working along the grain of pejorative readings of 'snapshot' photography, this account views the repetitiveness and redundancy of the cliché as a critical point of departure, rather than a cause for reproach. Taking the World Heritage Site of Angkor as a core case study, three intersecting axes of political concern are sketched out to elucidate the broad social, material and affective implications of clichéd photography for heritage. First, processes of dehistoricisation and depoliticisation are interrogated in relation to the role certain images play in constructing a mythic sense of the past in the present. This leads directly in to the second strand of analysis, which examines the various ways in which individuals negotiate these myths through the production of their own highly personalised photographic clichés. Here I develop the concept of an embodied politics of heritage photography to grasp the multivalent resonances of tourist clichés in particular. Finally, the implicit and explicit forms of spatial control that permeate sites such as Angkor are examined in relation to the photographic clichés they respond to and help shape.

Keywords: Heritage, Photography, Cliché, Mythscapes, Ideology, Affect, Angkor

'A tremulous image confuses and multiplies the photographed object' (de Certeau 1984: 100)

\section{Introduction: Affective Clichés}

Heritage can take many forms, but perhaps its most visible and coherent manifestation (in the Western context at least) has been the site. From stately homes and classical ruins to historic town centres and natural landscapes, certain localities have been separated from the flow of everyday life through a process of 'heritagisation,' an ungainly term that - in the context of the site - may encompass listing, conserving, documenting, interpreting and managing remnants of the past in the present (Harrison, 2015: 36). These ideas and practices have been exported, adopted and transformed through various interactions between different socio-cultural groups, including those for whom the very notion of site-based heritage may have previously seemed incongruous or even inappropriate. As many scholars have noted, these processes are intimately bound up with the construction of value, and must be understood in terms of discourse and the exercise of power (Brett, 1996; Butler, 2006; Byrne, 2008; Choay, 2001 [1992]; Smith, 2006). Issues of cultural representation are central to such discussions, with certain depictions, views, images and symbols seen to promote and regulate how heritage is perceived, valued and understood by varied constituents (Watson \& Waterton, 2010). These discursive practices impose further conceptual limits on the already bounded material 'site,' and while most places will be documented and portrayed through a multiplicity of media and towards a variety of aims, some forms of representation gain such currency that they become iconic, emblematic or even metonymic symbols of and for heritage. It is these highly conspicuous signs and images I am particularly concerned with in this paper, interrogated here with reference to the interrelated concepts of the myth and the cliché.

To suggest that heritage and myth are closely aligned is hardly a radical proposition. Historical narratives, archaeological sites, tourist marketing and curatorial practices are all caught up in the constant making and remaking of mythical conceptualisations of the past in the present. Although stated in different terms and with different accents, this insight courses 
through the foundational work of Eric Hobsbawm and Terence Ranger (1983), Pierre Nora (1989), David Lowenthal (1985) and Stuart Hall (1999). For these and other early writers on heritage, the myth of nationalism in particular was a central concern. As Harrison writes, since at least the late eighteenth century, 'officially sanctioned forms of heritage have functioned as integral devices for the production of origin myths within which to root the histories, laws and traditions of nationhood' (Harrison, 2013: 142). These processes and practices have given rise to what Duncan Bell calls 'the mythscape,' loosely defined as 'the page upon which the multiple and often conflicting nationalist narratives are (re)written; [the mythscape] is the perpetually mutating repository for the representation of the past for the purposes of the present' (2003: 66). While this definition may suggest an openness and variability to the mythic, for Bell, such representations are inherently reductive. 'The myth,' he argues, 'serves to flatten complexity, the nuance, the performative contradictions of human history; it presents instead a simplistic and often uni-vocal story' (Bell, 2003: 75). It is against this backdrop and under such circumstances that the social and political resonances of the cliché can be seen to take hold.

As a concept, the cliché is intimately bound up with hackneyed turns of phrase, overly repetitive visual representations and pedestrian categories of (usually touristic) experience, but there is also a more expansive history at play here. As Jonathan Meades writes:

We are all of us prey to itineraries of what is already mediated by prose and photography and television, the prepared scapes, the ready-made vistas, the off-the-peg sublimity, the store-bought sites of emetic picturesqueness. It was always thus: hence the majority of Grand Tourists of a quarter of a millennium ago took in the same places and were forever running into each other. We see what we have been taught to see. We visit places we have been enjoined to visit. We line up our eyes along the axis of an anonymous photographer's lens. We try to duplicate the very position that a perspectivist long ago adopted for his easel. We behave in this regard with apparently conditioned gregariousness

Above and beyond its characteristic glibness, what this passage makes clear is the need to situate any reading of photographic clichés (the focus of this paper) within a broader cultural matrix of clichéd aesthetics, experiences and practices. In the context of heritage, such clichés may encompass orchestrated tourist encounters, trite interpretive strategies, and the overuse of certain historical objects, narratives or expressions. One thinks here of the proliferation of documents and reports asserting the importance of securing 'a future for the past,' or the sheer volume of identical 'once in a lifetime' excursions available to sites on the UNESCO World Heritage List. Photography is clearly entangled with such phenomena in countless ways - indeed, part of the reason for my prioritising the photographic cliché in this paper lies in the critical efficacy afforded by such an embedded and wide-ranging social practice. At the same time, however, it is my contention that the clichés generated through and by photography may represent a unique and hitherto underappreciated setting for research and analysis in critical heritage studies. Crucial to this discussion is the multidirectional nature of the photographic cliché, which points both to the mythic representations of heritage as ideology, and to the embodied 'more-than-representational' (Lorimer, 2005) moments of heritage experience. This paper follows the same trajectory by first exploring the negative connotations of the cliché within photographic theory, before turning to theories of affect to determine the latent political possibilities of the repeated photographic gesture. This model is then applied to the case study site of Angkor, where I move from a broadly historical analysis of the emergence of certain visualities to a consideration of the touristic experience of the site today, explored through ethnographic research at key photographic 'hot-spots' (Angkor Wat, The Bayon, Phnom Bakheng, Beng Mealea). This approach draws out the layered political resonances that emerge as 
we progress from reading photographs simply as images to seeing the performance of photography as part of a broader complex of meaning-making and affect.

\section{Photography and the Cliché}

The cliché has long been framed in a disparaging light by historians and theorists of photography. In his 1983 work Towards a Philosophy of Photography, Vilém Flusser writes contemptuously of 'snapshots' as being 'redundant' and ultimately 'superfluous' to the subject (2000 [1983]: 26), with people (i.e. tourists) 'consumed by the greed of their camera' in certain contexts (Flusser, 2000 [1983]: 58). This line of thinking amplified Sontag's belief that 'the very act of taking pictures is soothing, and assuages general feelings of disorientation that are likely to be exacerbated by travel' (2002 [1977]: 9). While offering a more sustained engagement with amateur photographic practices, Pierre Bordieu's well-known study Photography: A Middle-Brow Art also stressed the redundancy of the cliché, with tourist photographers caught up in a 'paradox of consecration' where unique individual encounters are recorded in exactly the same way and under near identical circumstances by thousands of others (1990: 36).

Rather than seek to overturn these criticisms, my own interest in the cliché explicitly operates along the grain of notions such as redundancy, repetition, superfluousness and the picturesque. What I add to these debates however is a concern for the varied political implications of the cliché, particularly in relation to the conceptualisation, experience and management of heritage. Central to this inquiry is a concern both for how the photographic cliché functions socially, politically and culturally with respect to heritage, and a desire to understand the material and affective reverberations of clichéd image-making practices.

In much of the literature surrounding tourist photography, the notion of a hermeneutic circle is invoked to explain the production of clichéd images, with travellers 'certifying and sealing' experiences via photographs that recreate views first encountered in guidebooks and other media (Albers \& James, 1988: 136; see also Urry, 2002). While this circularity is discernible across various kinds of photography associated with sites of heritage - especially in relation to the cliché - observations that stress the hermeneutics of this process can only take us so far. Indeed, it is my contention that the noteworthy links between mythic representations, tourist marketing and 'on the ground' photographic engagements with place are more nuanced and fragmentary than this closed system model would suggest. To fully understand the diverse political consequences of overtly repetitive photography, we must simultaneously get inside the hermeneutics of the cliché and examine its varied impacts on the world. This double orientation structures the following discussion.

During the 1980s, photographic theory tended to focus on the ideological structures in which images were embedded, ideology here being 'a system (with its own logic and rigour) of representations (images, myths, ideas or concepts, depending on the case) endowed with a historical existence and role within a given society' which acts on men and women 'by a process that escapes them' (Burgin, 1982: 5). More recently however the domain of amateur photography has been seen to offer scholars an alternative means of apprehending the political (Pasternak, 2013). This is because 'amateur photographic landscapes [...] could be said to constitute political

(rather than social) melting pots, where personal and intellectual aesthetics, as well as artistic, professional, commercial and technical aspirations are acted out in relation to, and against each other' (Pasternak, 2013). Such practices 'exist within spaces organised by social powers,' but have no direct, willing affiliation with overarching ideological institutions (Pasternak, 2013). They are

sites of contestation and negotiation, with the photograph emerging as a vehicle and apparatus for the mediation of different narratives, meanings and self-identities (Stylianou-Lambert, 2012: 1836). In the context of heritage, we thus begin to see why photography - and the photographic cliché in particular - can be leveraged as a site of political and not just aesthetic enquiry.

Walter Benjamin's definition of the 'aura' has been influential across these debates, surfacing in otherwise unrelated discussions of heritage and photography (e.g. Duttlinger 2008; 
Malpas 2008; Zhu 2012). Famously declaring that the 'aura of the work of art' may depreciate through mechanical reproduction, Benjamin argued that 'the authenticity of a thing is the essence of all that is transmissible from its beginning, ranging from its substantive duration to its testimony to the history which it has experienced' (2007 [1936]: 221) By effectively removing objects from this 'changeable fabric of tradition' (Jones, 2010: 189), Benjamin believed photographic and other mechanical forms of representation would destroy the auratic power of the original. While the notion of a layered, biographic authenticity remains prevalent in many contexts, countless examples from Stonehenge to the Mona Lisa demonstrate that the aura has rarely wilted in the way Benjamin predicted. In fact, viewing an object from afar may accentuate the desire for direct experience, for personal engagement with the 'authentic' thing: 'the more we have learned to understand all images, words, and sounds as always already mediated, the more it seems we desire the authentic and the immediate' (Huyssen, 2010: 20). As Siân Jones rightly points out, a kind of 'magical communion' may occur through this deepening familiarity (2010: 189), with individuals incorporating themselves into the network of relationships that surround historical or artistic objects. That this integration of person and thing will often involve photographic documentation - or proof of experience - gestures towards a further significant point in our analysis of the cliché.

In certain cases, the power of photography to shape the world may be said to lie not in highly distinctive images (as Flusser would suggest), but in the sheer volume of similar photographs depicting the same location or subject. What knowledge about the past in the present does the cliché produce and what does it obscure under these circumstances? What is left out and what is underlined in the overt repetition of certain images, and how might heritage practitioners work along or against the grain of these processes to confront the limitations and possibilities of the cliché? Furthermore, from the perspective of the individual photographic encounter, how might a revised appreciation of the cliché provoke new understandings of the affective power of heritage in various forms? Such lines of enquiry are designed to focus an interrogation of the simple yet profound point that so many sites of heritage will be photographed over and over in the same way by remarkably different constituents. To fully grasp the implications of this phenomenon we must transcend any simplistic cynicism and begin to recognise the cliché as a particularly provocative constellation of heritage and photography.

\section{Whither Affect?}

The shift away from a focus on ideology within theories and histories of photography and towards a prioritisation of individual negotiations with social power echoes broader debates around discourse and affect within heritage (see Tolia-Kelly, et al., 2017). This trend has recently been critiqued with characteristic precision by Gary Campbell and Laurajane Smith (2016). In light of such criticisms, I would like to briefly explain the rationale underpinning my own turn to affect in this paper.

There are two important and interconnected strands to affect that I want to draw out over the following pages. The first relates to the bodily intensities and pre-cognate forces that theories of affect foreground, while the second concerns the capacity to change and be changed that resides in and emerges from different bodies (human and non-human). Here I follow Kathleen Stewart in pursuing 'affects that arise in the course of the perfectly ordinary life as the promise, or threat, that something is happening - something capable of impact [...] they take us to the surge of immanence itself (2005: 1029). Combining this with Tolia-Kelly's (2006) view of affect as embedded and transmitted through wider cultural forms, we can begin to see how practices of heritage and photography might shape and be shaped by the affective realm. As Tolia-Kelly (2006: 3) writes, 'the affective represents the ways in which flows of emotion coalesce to form a social phenomenon that is beyond the individual subjective responses, feelings, and sensibilities'. Zembylas summarises these two strands in suggesting that affect be understood 'both as a process and a product. a process in which one body acts upon another, and a 
product in the sense of a body's capacity to affect and be affected' (2006: 309, original emphasis). As a result, 'it is not just a feeling or an emotion but a force of energy that influences a body's modes of existence' (Zembylas, 2006: 309). Examining photography and heritage within this framework would suggest avenues of research that converge upon the 'bodies' (e.g. images, objects, sites, people, technologies) caught up in 'processes' of heritage making as well as the 'products' of their affective force - i.e. the results (sensual, material, conceptual) that the emergence and - crucially - movement of bodies provokes (see Thrift 2008 for the importance of movement to theories beyond constructivism). My own turn to affect is prompted by these concerns, and is consequently centred around the 'sensual intensities' (Navaro-Yashin, 2009: 12) generated by the photography complex as it interacts with heritage, as well as the processual 'bloom-spaces' (Gregg \& Seigworth, 2010) that surface within and come to define these interactions. In research terms this demands an alertness to issues beyond discourse: as Guattari makes clear, affect is first and foremost 'non-discursive [...] hazy and atmospheric' (in NavaroYashin, 2012: 168).

Working against this grain, Campbell and Smith have recently argued that the currently fashionable theories and concepts of assemblage, flat ontology, agency and affect drawn from New Materialism and Post-Humanism represent something of a critical and methodological dead-end for heritage. By focusing on materiality, these authors argue, we are liable to miss the social, human and political contexts and resonances of heritage. Notions such as intensity and contagion are particularly derided in this analysis, which rightly points out that most heritage research is simply unable or unsuited to register the kinds of precognitive and prediscursive dimensions of embodied experience that undergird affect. As Campbell and Smith suggest:

[a] rather over-excited focus on febrile affect, which it seems is the basis for action and change, completely ignores the kinds of affect that are flat and a bit boring really, those instances when lack of intensity is actually the bodily response, which is in itself an affect, in instances when remaining unmoved and disinclined to action are actually political acts, or in a sense non-acts. Flat affect leads to the refusal to extend empathy and compassion, and leads to inaction, to conservatism, but this is not an exciting or easy line of inquiry to follow.

(2016: 9)

In a very real sense this is precisely the challenge I take up in the present paper by prioritising the mundane as a critical line of enquiry. The kinds of imagery associated with the cliché can certainly be considered 'flat' and 'a bit boring.' They are conservative, and often preclude or at least delimit political action. But the mundane nature of these clichés also carries an implicit potential, and this is recognised by Brian Massumi (one of the foremost authors on affect, and a particular target for Campbell and Smith's critique) when he describes the affective politics of the event. Massumi's recent thoughts on this issue are worth quoting in full here:

Even in the most controlled political situations, there's a surplus of unacted-out potential that is collectively felt. If cued into, it can remodulate the situation. As Deleuze and Guattari liked to say, there is no ideology and never was. What they mean by that is no situation is ever fully predetermined by ideological structures or codings. Any account paying exclusive attention to that level is fatally incomplete. No situation simply translates ideological inculcations into action. There's always an event, and the event always includes dimensions that aren't completely actualised, so it's always open to a degree, it's always dynamic and in re-formation. To be in effect, ideological predeterminations have to enter the event and take effect. They have to reassert themselves, to make themselves effectively ingredient to the event. Their effectiveness is always an accomplishment, a renewed victory, and what needs to be accomplished can 
fail. Micropolitics, affective politics, seeks the degrees of openness of any situation, in hopes of priming an alter-accomplishment. Just modulating a situation in way that amplifies a previously unfelt potential to the point of perceptibility is an alteraccomplishment

(2015: 58, emphasis in original)

This passage gestures towards a number of critical issues I aim to explore in the present paper. In the embodied moment of clichéd image production, ideologies of heritage - what I refer to here as the mythic - are constantly renegotiated or 'remodulated,' to borrow from Massumi. Indeed, it is the very individuality of the cliché - marked by a visual and experiential repetition that nevertheless depends on subtle shifts to be articulated with each new production - that makes it such a useful point of conceptual and methodological analysis for heritage. The phenomenological work of Merleau-Ponty is instructive here, highlighting as it does the productive nature of our embodied encounters with the world (2004 [1948]). Understanding heritage visitation from this perspective would suggest that individuals are never mere spectators - their involvement in the world of the site marks out multiplicitous borders of perception while simultaneously opening out onto new perceptual and performative horizons (Merleau-Ponty in Tilley, 1997: 12). These performances represent the site at which the significance of things may be subtly adjusted, focusing our attention on 'the unexpected and the divergent in the excess of multiple possibilities of what people do' (Crouch, 2015: 180). Mundane should not be seen as a disparaging term in this context. Rather, it is intended to evoke both the widespread predictability of heritage experiences alluded to by Campbell and Smith, and the tensions that arise in negotiating what are often perceived and promoted as extraordinary places via ostensibly trite representational practices. Against this backdrop, the extent to which the cliché may prevent or permit the kind of alter-accomplishments described above by becoming more than simply a 'non-act' is a key concern of this research. Following Waterton and Watson - but directly confronting some of the methodological shortcomings of their work (see Sterling, 2014) - my aim is thus to trace the social and not just subjective contexts of affect (2013: 556). To help explore these issues, I would now like to introduce Angkor as an exemplary case study in the relationship between myth-making, heritage and the photographic cliché.

\section{Angkor as Banal Utopia}

Ever since its 'discovery' in the 1860s, Angkor has been subject to an ever-expanding circulation of images, signs and representations. The earliest of these can be traced to Henri Mouhot, a French naturalist and explorer who made a series of journeys across South East Asia between 1858 and 1861 (1966 [1864]). Mouhot died in the jungles of Laos, but his diary was posthumously published in nine instalments of the magazine Tour de Monde during 1863. This serialised account featured engravings based on Mouhot's own drawings, including the first known sketches of Angkor (Figure 1). ${ }^{\mathrm{i}}$ As Anthony Barnett writes in his essay 'Cambodia will Never Disappear' (1990), the publication of Mouhot's diary 'dramatised' the revelation of Angkor for European audiences, highlighting the possibility of a 'marvellous cultural appropriation' (Barnett, 1990: 112). This occurred at a turning point in France's involvement with the region as a whole. Mouhot's description and - crucially - visualisation of Angkor would thus help fuel the French popular imagination, assisting in a broader 'mythologising conquest of Indochina' (Cooper, 2001: 17).

\section{INSERT FIGURE 1}

In the context of Cambodia, the myths pursued and constructed by the French were rooted in a dehistoricisation and depoliticisation of the ruined temples of Angkor. Mouhot, of course, did not discover this site. As his own diary records, Angkor Wat in particular was already famous 
locally and regionally, having remained an important site of pilgrimage and religious activity for Buddhists from the fifteenth to the nineteenth century (Chandler, 1993: 29). Indeed, when the photographer John Thomson visited the site in 1866, his travelling companion H. G. Kennedy recorded a bustling scene:

About thirty or forty priests have fixed their habitations under the shelter of the ruins, and find a never-failing employment in conducting the obsequies of those whose bodies are brought to this highly-venerated sanctuary for cremation; and when to the music and feasting, which forms part of such ceremonies, we add the constant influx of visitors who come to make offerings at the shrine, it will be seen that it was not in forest loneliness, but rather amid a busy scene of life, that we were established

Worth noting here is the fact that little of this life made its way into Thomson's photographs, which were the first to be taken at the site (Figure 2). This is partly to do with the technological limitations of the camera at the time, but it must also be understood within the context of a Western imagination that sought to separate and romanticise exotic ruins for aesthetic contemplation. As Barnett describes, the existence of Angkor was 'an interesting surprise, but that something like Angkor could exist - the ruins of a despotic Oriental civilisation discovered by Western explorers - was a splendid (in all senses) confirmation of the already existing European worldview' (1990: 115). Representations made under the rubric of colonialism, as Edward Said has shown, need to be studied with reference to the political power they express (1994). The emergent visual cliché discernible in Mouhot's sketches and Thomson's photographs should thus be seen as part of a wider complex of colonial myth-making at Angkor; processes which would have wide-ranging and often pernicious consequences for the site and its inhabitants.

\section{INSERT FIGURE 2}

France's authority over Angkor intensified after 1907, when the region around the temples was ceded to the French protectorate of Cambodia by Siam (Thailand). In the same year, the École Francaise d'Extrême Orient (EFEO) was charged with recording, preserving and restoring the site. The first half of the twentieth century subsequently witnessed an outpouring of research into the history of Angkor, while a steady stream of tourists also began to visit the temples (Di Giovine, 2009: 53). Under these circumstances, increased historical and archaeological knowledge of the site coincided with reductive strategies of myth-making. As important conservation work was carried out, so new tourist perspectives were created. Far from being incongruous, such practices were mutually constitutive. By the 1930s, Angkor War in particular had been substantially landscaped, creating a host of picturesque new photo-opportunities (Falser, 2013: 95). Guidebooks were also produced to help visitors navigate the site. These contributed to a radical 'decontextualisation' of the temples, transforming what had been a site of local and regional Buddhist social practice into a 'stylised heritage reserve of dead colonial archaeology' (Falser, 2013: 82). This process echoes a wider trend across the region (and indeed around the world) which has seen the iconic function and material integrity of historic sites take precedence over their spirituality (Byrne, 2004). Such practices deploy the photographic cliché - and other stereotypical forms of representation - to promote and perpetuate certain conceptualisations of place. During much of the twentieth century this was bound up with different modes of colonial control and appropriation. While more recent articulations of the cliché are perhaps less directly implicated in the administration of Angkor, they can still be seen to exert a hold over the way the site is perceived and ultimately experienced by varied constituents. This is particularly true when we consider the vast expansion of tourism the site has faced over the last three decades. 
Beyond the 'official' narratives of heritage making, there lies then a vast reservoir of mythic signs, symbols, images and stories. Many of these are located in the domain of tourism, and are intimately bound up with the commodification of space (Edensor, 1998). As the sociologist Rob Shields noted as early as 1991, people's perceptions of particular places are indebted to 'place-myths': conglomerates of images, stereotypes and clichés that encircle and animate particular locations, and 'derive their durability, spread and impact from repetition and widespread dissemination' (Crouch \& Lübbren, 2003: 5). Visual representation clearly has an important role to play in the generation of such place-myths, with iconic images conjuring up thoughts and opinions about whole regions, sites or groups of people. In the words of Watson and Waterton, visual images are 'intimately embedded in the mechanisms that construct and make real a range of imagined, historic and/or mythical places' (2010: 11). Following the work of John Urry (2002), this has given rise to a consistent body of analysis within heritage critiquing tourist brochures, guides, postcards and other modes of visual discourse; these media being 'just as implicated in the processes of conveying power and status as more explicitly ideological texts' (Waterton, 2010: 157).

For Tim Winter, the tourist imagery circulating around Angkor has 'resolidified' the myth of discovery and exploration that first animated European audiences (2006: 56). The cliché here is one of a lost, ruined civilization buried in the jungle, with mysterious carved faces emerging from the undergrowth and fog shrouding enigmatic temples (Figures 3 and 4). Above and beyond inviting an Indiana Jones style exploration of Angkor, such representations are entwined with a conceptualisation of the site that paradoxically emphasises a 'vacuum of history' (Winter, 2007: 30). This realisation underscores one of the key affective trajectories of the cliché; namely its reductive production of place.

\section{INSERT FIGURES 3 AND 4}

The types of processes at work here have been detailed by Marc Augé in his well-known characterisation of the 'non-place,' a term which marks out localities that 'cannot be defined as relational, or historical or concerned with identity' (1995: 63). To suggest that sites of heritage may fall into this category seems counterintuitive, and yet for Augé well known buildings, monuments or territories (e.g. the Eiffel Tower, Pisa, Angkor Wat) are liable to lose their historic or relational potency even while defined as 'places of memory.' Certain sites, he argues, are so familiar they exist only 'through the words that evoke them, and in this sense they are non places, or rather, imaginary places: banal utopias, clichés' (Auge, 1995: 77). Tellingly, the 'travellers space' of the tourist brochure image is held to be the 'archetype of non-place' in this analysis (Auge, 1995: 77). Here then Augé illuminates one of the fundamental dangers of clichéd photography, namely that an over-familiarity engendered through images might in turn foster a lack of affective engagement, both with the complex histories of a site and the wider possibilities of what that site might mean to the present and the future.

Following his own touristic expedition through French Indochina in the late 1930s, English writer Osbert Sitwell would suggest that 'it should be unnecessary now to have to state how profound a gratitude, for the preservation and opening out of Angkor, all lovers of beauty must owe to the French authorities in Cambodia' (Sitwell, 1984 [1939]: v). While more recent preservation initiatives have been enacted by an increasingly diverse range of nations and quasiautonomous organisations (e.g. Korea, Germany, Japan; The World Monuments Fund, Global Heritage Fund), a sense of cultural appropriation lingers over the site. As Winter has argued, the world heritage framework underpinning such activities has meant that the way Cambodians themselves may value Angkor as a 'lived space' and a 'landscape in constant flux' has been 'marginalised within a discourse of monumental grandeur and classical antiquity' (2008: 536). The various photographic clichés that have emerged under and helped shape these circumstances perpetuate a 'myth of changelessness' wherein Cambodia is perceived to be 
'asleep' and unable to break into a new kind of life (Chandler, 1993: 2). Dehistoricised and depoliticised, such imagery risks leaving Angkor adrift as a banal utopia of jungle ruins, bucolic landscapes and superficial religious encounters. The audiences for this type of photographic representation are varied, but there is a sense that the cliché epitomises and helps reinforce a detached Western gaze unable to comprehend the complex 'reality' of Angkor as a lived world. To understand how the top-down politics of these place-myths might be negotiated at the level of the event and the encounter, we must turn to the embodied moment of photographic creation; a material-discursive space in which the potential for clichés to 'remodulate' conventionalised heritage practices is played out on a daily basis.

\section{Towards an Embodied Politics of Heritage Photography}

It is a short journey by car, bicycle, túk-túk, coach or scooter from Siem Reap to the main entrance of Angkor Archaeological Park. This route, normally thick with traffic, is noticeably calmer in the pre-dawn hours. That is until you reach the ticket office itself. Here, a throng of visitors belies the early hour, their objective all the same: sunrise at Angkor Wat.

These crowds continue within the World Heritage Site itself. Following the road north from the ticket office a mass of headlights reflects off the still waters of Angkor Wat's great moat. At the western entrance to the temple, official tour groups, small excursions and lone travellers gather, and soon a parade of hundreds if not thousands of visitors snakes along the central causeway of the complex, torches guiding their every step in the darkness. The vast majority soon peel off to the left of this path, seeking out a well-known spot where - if the time of year is right - a small body of water provides a reflective surface for the emerging sun. There is a jostling for position as tripods are erected and the most picturesque angles sought. And then soon, for milliseconds at a time, flashes illuminate the scene, as the sun begins to rise and the famous photo opportunity unveils itself.

In many ways this panorama has come to define the myth of Angkor, even appearing as part of the state-wide branding strategy 'Cambodia: Kingdom of Wonder.' Countless variations on this theme can also be found online, testament to the thousands of photographers who have recorded the spectacle. While it would therefore be misguided to imagine that the familiar tranquillity of the site as represented might be carried through to the moment of photographic encounter, the gap here between visual-discursive construction and affective experience is striking. The clammy, frantic and overtly collective moment of photographic creation played out in this context is regulated in the serene imagery produced by tourists, who push and pester each other to get a clear shot of the sunrise (Figure 5). Within the framework of tourist hermeneutics, visitors to Angkor Wat may be said to seek out the sign of the sunrise first encountered in varied travel literature (online and printed), before gazing at and photographing this sign in a moment of detached yet embodied engagement, 'one step removed from a visceral and emotional encounter with the objects themselves' (Crouch \& Lubbrën 2003: 8). The cliché of the Angkor Wat sunrise exemplifies this process, promoting and anticipating a certain category of experience, which is then 'certified' and 'sealed' by the travellers own photographic productions, reaffirming 'the privileged position of photography as a source of [the tourist's] own awareness' (Albers \& James, 1988: 136). Such representational practices draw attention to the appropriative dimensions of tourism: excessively concerned with an idealised aesthetic, and interested only in the production and consumption of 'banal utopias' (Augé, 1995). To what extent we might reconceptualise the photographic cliché as a means of unravelling these crude assumptions is the core concern of this section.

\section{INERT FIGURE 5}

As already mentioned, this conceptual reorientation is closely tied to Massumi's definition of 'affective politics' (2015), a model which helps reinstate tourist subjects as 'participatory agents' in the generation of meaning (Crouch \& Lubbrën, 2003: 11). Here I closely follow the work of 
Edensor, who has argued for an appreciation of tourist photography that looks beyond the notion of an 'abject, facile and mindless subject who can do no more than simply reproduce banal styles and themes' to consider instead the 'enlivened body of the engaged photographer' (2014: 25). This line of research does not abandon the discursive regimes that have been shown to structure heritage, but rather expands on this critical lens to take into account other trajectories of meaning making and affect - notably around the corporeality of the photographing body. To this end, my principal area of investigation here is the photographic act - a mode of 'kinaesthetic appropriation' (de Certeau, 1984: 97) that can be playful, exploitative, distancing, aggressive, creative, tactless, rebellious or - as the title of the present paper suggests mundane. To get inside the 'more-than-representational' (Lorimer, 2005) movements and disturbances of such a photographic apprehension of space demands a qualitative and participatory approach, one that follows the common patterns and structures of tourism but remains alert to the varied textures of photographic practice.

Such affective situations abound across Angkor. Standing as enigmatic testaments to the reign of King Jayavarman VII, the serene faces of The Bayon for example have long captivated visitors to the site (see Higham 2001; Mouhot, 1966 [1864]). Today, through tricks of photographic perspective, many tourists at the site will engage with these faces by pretending to kiss or rub their noses against the profile of the sculptures. Guides helpfully point out the best positions from which to compose such images, and there will often be a disorderly queue waiting to form their bodies into the requisite stance at these spots (Figure 6). Like 'pinching' the Taj Mahal or 'supporting' the Leaning Tower of Pisa, the photographic construction of such scenes speaks of a ludic or even subversive encounter with monumental sites of heritage. In these contexts, the knowledge of previous representational practices combines with a desire to verify one's own experience to initiate a distinctly photographic and personalised appropriation of space. As Jonas Larsen has argued (2012), the element of play is important to understanding such encounters. Rather than accentuate the photograph as an expression of 'emotional intensity' (Waterton \& Watson, 2014: 31), Larsen suggests that moments of play and performance themselves become the focus of our analysis, highlighted as a source of both pleasure and creativity (2012). The political importance of the cliché is not sidelined in this reading, but is instead shown to operate along occasionally surprising trajectories.

\section{INSERT FIGURE 6}

While clichéd experiences and photographic practices are to be expected at a site as well-known as The Bayon, temples such as Beng Mealea, which sits around $40 \mathrm{~km}$ east of the main Angkorean ruins, can still be visited in relative solitude. Built in the twelfth-century under Suryavarman II, the main structure for this temple follows (or perhaps precedes) the template of Angkor Wat, with a vast moat surrounding the main complex (now largely dried up), four entranceways, and three enclosing galleries around a central tower. Here, the quiet of the site is matched by its derelict state, with a lack of any significant restoration work creating an unmistakable sense of 'discovery.' As a result, guidebooks proclaim Beng Mealea the 'ultimate Indiana Jones experience' (Lonely Planet, 2012: 153). ${ }^{\text {ii }}$

It is therefore highly telling that, even in this relatively isolated location, the act of photography has attained such a familiar currency that unofficial guides at the site will direct visitors to certain points of view, certain compositions, and certain visual and bodily enframings. During fieldwork in 2012, for instance, a local caretaker led me across the site, first drawing a map of the ruin in the sand before pointing out key architectural elements such as finely carved apsaras, strange animal reliefs, and a relatively well-preserved library building (Figure 7). Navigating the temple in silence (a result of the language barrier), my guide would halt at various junctures and gesture towards a particular spot, forming his hands into the unmistakable shape of a body about to photograph and repeating 'picture, picture' until I followed his command and 
captured the scene. These photo opportunities ranged from the evocative sight of a tree emerging from the summit of a ruinous tower (an iconic symbol of Angkor as a whole), to the personal framing available through the fortuitous growth of a vast root into the shape of a swing. Although organised around a local, vernacular knowledge of the site, this itinerary clearly owed much to the interest previous visitors have shown in certain viewpoints, as well as the documentation and promotion of the temple in tourist literature and - perhaps - more 'official' heritage related visualisations. Crucially, then, while Beng Mealea is far less prominent than sites such as Angkor Wat, The Bayon or Ta Prohm in the photographic life of Angkor, we are still led here towards a selective documentation; prompted, in other words, to cliché.

\section{INSERT FIGURE 7}

While such comportments can be seen to accentuate those processes through which 'place consumers draw upon their imagination and memories to reconfigure heritage sites and landscapes' (Selby, 2010: 44), they are also part of a broader and potentially more pernicious transformation of Angkor. One of the key issues at stake here is the fact that photography may be seen as giving rise to a sense of touristic ownership over a site, acting as part of a discursive and affective appropriation of space that works against local cosmologies. Winter's analysis of tourism at Angkor is again instructive in this respect, highlighting as it does the troubling realignment of the site as a 'cultural enclave [...] socio-historically disembedded from its Cambodian context' (2007: 91). Drawing on the work of de Certeau, Winter sees this touristic consumption emerging across 'an ensemble of spatial enunciations [...] where place becomes meaningful through its "kinaesthetic appropriation" (Winter, 2007: 20). As one of the fundamental practices of modern tourism, photography may from this perspective be seen as transformative in terms of the bodily contortions and aesthetic engagements the particular technology and materiality of the camera engenders. To suggest however that photographic clichés might countermand dominant techniques of spatial organisation and control (the aim of kinaesthetic appropriation for de Certeau) would be wholly misleading. Indeed, while the individuality of tourist clichés underscores the need to examine photography as a corporeal phenomenon, the constant (re)production of such a limited visual repertoire also hints at the suppression of value systems that might contradict 'authorised' heritage practices (Smith, 2006). At Angkor this means that the site is routinely framed as 'a set of ruins frozen in time' rather than a living heritage and an important constituent of identities still very much in flux and reconstruction' (Winter, 2006: 115). Such a reading emphasises the need to remain alert to the political and ethical implications of photography as an affective apparatus of heritage meaningmaking. As Waterton and Watson argue, 'the same dynamics that operate behind the scenes of representation and discourse will operate behind the scenes of engagement and performativity, limiting what is enactable, prescribing what is appropriate, writing or affording particular emotions and affects into its scripts' (2014: 121).

Further to this, what studies emphasising embodiment and kinaesethetics also routinely fail to note are the impacts of the body - and especially the repeated body - on the material world. This line of enquiry is vital for heritage conservation, where the body is often understood as a thing to be managed and manipulated to avoid damage to historic sites or objects. The cliché is particularly relevant as a point of analysis here because it highlights areas of intense experience not just in the sense of personal subjectivities and emotions, but in terms of physical impact. At Angkor, this has long been tied to the prioritisation of certain spatial practices over others and the imposition of boundary markers that define localities across the Archaeological Park in different ways (Falser, 2013). In this respect the site clearly rehearses the 'Kodakization' of tourism as defined by Crouch and Lübbren, which involves marking out directions of view and guiding visitors along enframing circuits of visual culture (2003: 9). To this end, one of the most palpable signs of photography's transformative potential at Angkor is found in the numerous 
strategies of touristic control that now permeate the site. Designed to alleviate the impact of mass tourism on the fragile temple ruins, these protective measures are to some extent motivated by the very form of the camera-wielding tourist, becoming then a tangible manifestation of the more-than-representational affects of the photographing body. As Stanley Milgram suggested, photography has 'created a new choreography of gestures and movements that did not exist before the creation of photography' (in Stylianou-Lambert, 2012: 1830), and these must be controlled and regulated in contexts where the sheer volume of individual photographers' risks becoming a source of material injury. Understanding the embodied engagement of the cliché takes on a marked urgency in such contexts.

Ta Prohm is a case in point here. Responding to issues of visitor safety and material preservation, a series of wooden platforms has been constructed across this site as a means of controlling where and how people interact with particularly fragile or well-used parts of the temple complex. Tellingly (and unlike at other sites such as Banteay Srei or Beng Mealea), these platforms are oriented so that visitors might use certain evocative elements of the temple as a backdrop to their photographs without physically touching the structure (Figure 8). At one particular spot, this will often involve 'playing up' to the camera in mimicry of Angelina Jolie's portrayal of Lara Croft in Tomb Raider, which was partly filmed at the temple. In this sense the platforms make tangible Edensor's analysis of tourist photography as the 'dramatisation' of sites and events to aid the recounting of holiday narratives (1998: 138), a reading that draws together the performative and memorial connotations of the clichéd image (see also Larsen, 2006).

\section{INSERT FIGURE 8}

A less visible but no less significant materialisation of the changes made to accommodate mass photography can be found in the Angkor Sunset Finder, a digital guide launched in 2013 to encourage visitors away from well-trodden sunset viewing sites such as Phnom Bakheng. Designed by UNESCO, APSARA and the Australian heritage consultants Godden Mackay Logan, the sunset finder explicitly aims to 'spread visitor load across the park,' providing benefits to local communities and offering 'new attractive opportunities for visitors' (Angkor Sunset Finder, 2013). The first temple-mountain built in what became the main Angkorean complex, the 70 metre summit of Phnom Bakheng provides views of the Siem Reap plain, the Western Baray, Phnom Kulen, and the temples of Angkor Wat and Angkor Thom. As Califano notes, however, the original symbolic significance of the temple structure and its location is somewhat overwhelmed by the sheer spectacle of the sunset (2005), and even with limitations on visitor numbers, there is a sense that Phnom Bakheng is 'overrun' by tourists each evening. In 2005 a report by the World Monuments Fund described the impact of this time sensitive gathering as 'catastrophic' (Sun Kerya, 2005: 138), and - alongside the sunset finder - direct place-making strategies have been implemented to alleviate the effects of mass tourism. These include the construction of new routes into and across the site, with carefully managed 'stopping points' providing 'panoramic views' and alternative 'photographic opportunities' (Sun Kerya, 2005: 146).

The need for these subtle touristic structuring mechanisms was brought vividly to the fore during my own experiences at Phnom Bakheng, a site where the chasm between representation and affect is of more than simply theoretical concern. While not all visitors to this location will see photography as a priority, a multitude of cameras are trained on various sights visible from the temple, most notably Angkor Wat bathed in the fading sunlight and the setting sun itself. There is a conspicuous divide here however between tourists who bring with them high-end photographic equipment (e.g. large DSLRs with telephoto lenses) and those who employ nothing more than a small compact camera or even smart-phone to take pictures (Figure 9). This divergence in photographic equipment speaks of a different mode of engagement and not just visualisation: a different way of being, not just seeing. Rather than simply pointing and shooting, the utilisation of expensive photographic technologies demands careful composition, 
awareness of light, patience and - most notably - planning and forethought (the Lonely Planet guidebook helpfully suggests a lens of at least $300 \mathrm{~mm}$ will be required to get a 'decent' picture of Angkor Wat from the summit of Phnom Bakheng (2012: 141)). Such practices visually and physically situate the tourist within a complex web of discursive and affective energies; an entanglement in which photography assumes a particular force as a prompt to meaning-making and an intensely embodied act of spatial appropriation. And while the particular types of image sought by tourists will owe much to pre-photographic representations, the intensification of the photographic act that has accompanied and to some extent shaped tourism has brought with it a series of material corollaries that demand the attention of heritage theorists and practitioners alike.

\section{INSERT FIGURE 9}

\section{Conclusion}

Like all sites of heritage, Angkor is 'more than simply a repository of cultural values, or an object of pure aesthetic enjoyment; it is the site of intense aesthetic re-imagining, and political and economic appropriation' (Norindr, 2006: 54). In this context the myth of Angkor has come to play a pernicious role, restricting what the site might mean and ultimately how it is managed and experienced for varied constituents. While this was particularly acute in the colonial era, the framework of 'World Heritage' has in many ways perpetuated a separation of the site from the lived complexities of Cambodia. Although recent strategies have begun to address these processes of marginalisation and subjugation (Hauser-Schäublin, 2011; Miura, 2005; 2012), mass tourism to the site continues to follow set paths and practices that both respond to and help shape the photographic clichés I have focused on in this paper. Here it is important to note that while such clichés do more than simply rehearse the mythic, even playful contradictions of authoritative promotional campaigns can be caught up in the appropriation (kinaesthetic or otherwise) of place.

The photographic clichés produced under such circumstances are part of a wider visualdiscursive network of representations encompassing fine-art practices, conservation work, journalism and quotidian photography. Indeed, it may be argued that heritage sites such as Angkor - prized for their mythical and historical value yet still home to diverse communities who may advocate different categories of significance - present a particularly fertile ground for photographic analysis. This is because processes such as commodification and 'museumification' are not just illustrated by photographs, they are actively played out through the visual domain; a domain which - as this paper has shown - is deeply embedded in broader socio-political structures and affective encounters with place. Against this backdrop Chris Pinney's recently announced 'Citizens of Photography' project, which looks to Cambodia as one of its main fields of investigation, should provide a welcome counterbalance to studies focused on representation from above.

The cluster of ideas brought together under the rubric of affect point in numerous analytical and methodological directions at once. While some of these paths may lack an immediate relevance to heritage, others have opened up important new lines of enquiry. Massumi's notion of an affective politics for example helps us to understand how ideological predeterminations remain malleable even in the most carefully structured heritage experiences. Following Waterton and Watson, this paper has argued that embodiment and performance are crucial to this dynamic, giving rise to what I have called an embodied politics of heritage photography. The contours of this framework are as follows.

First, a focus on the embodied nature of heritage experience helps us to understand the various ways in which individuals subjectively negotiate the ideological structures put in place by different systems of control and meaning-making. Following Dylan Trigg, this is because our bodies 'orient us in place, and in doing so become the primary source of how we apprehend a 
given environment' (2012: 6). The politics of this embodied comportment are two-fold. First, through a sensuous engagement with the world, 'degrees of openness' may be sought, providing conceptual and physical space for a 'remodulation' of the ideological structures governing any given situation (Massumi, 2015: 58). By centring embodiment, we thus highlight the possibilities latent in the experience and performance of heritage, rather than the stability of top-down representations. Working against this fluidity however we find the politics of bodily control, which - in the context of heritage - is closely aligned to the preservation of material residues of the past in the present. Here, a focus on embodiment helps accentuate the varied regulatory strategies that permeate heritage, from online guides to physical barriers. The body is crucial to this reading not because it is where 'the totality of experience in place begins and ends' (Trigg, 2012: 10), but because it is where interactions with and potential injuries to heritage are commonly located.

My focus on the politics of the photographic cliché at Angkor has helped clarify this dual orientation. The repetitive nature of the cliché emphasises the need to look beyond mythic visualities to understand the personal resonances and multi-sensuous encounters that define ostensibly mundane heritage experiences. At the same time, however, the incessant recurrence of the cliché has given rise to varied disciplinary structures that seek to cope with the repeated body, from photographic platforms to vernacular guided tours. Indeed, as my research at Angkor has shown, repetitive images need not be 'authorised' in any strict sense of the word to exert a sense of control and order that belies their ephemerality. Both these analytical nodal points respond to and remodulate the overarching ideologies of certain photographic conceptualisations of place, and we should not neglect these top-down formations when considering the politics of heritage. The key question here must be: to what extent can heritage practice facilitate rather than delimit representations and activities that stress fluidity and lived complexity over the reductive narratives of the myth?

There are many possible ways of addressing this problem. At Angkor, concrete strategies have been put in place to redirect visitors away from overly repetitive experiences. While this has primarily been prompted by concerns around material conservation, ripples may be felt in the broader perception and ethical management of the site (it is too early to make claims in this regard). More generally, we can I think begin to imagine a series of grounded reconfigurations of the field that confront the challenges and possibilities of the cliché. Such a practice would speak to the ongoing and unstable nature of the repeated image, which is always in a process of becoming and yet seems rooted to particular experiences and performances. It would actively pursue remodulations through education and playful intervention rather than wholesale control, and would seek to work with the material-discursive embeddedness of photography (not to mention its ubiquity) to experiment with alternative forms of heritage making and touristic performances. The photographic cliché can become an interlocutor in these processes, rather than the enemy. Through varied interpretive approaches and material interventions heritage practitioners are already engaged in the constant (re)production of stories and experiences that shift the meaning and affective potentialities of the things they care for and help promote. This heritage work is further caught up in the ongoing performances and gestures of heterogeneous subjects and audiences - there is no closure to such practices, 'no full script, no controlled tour' (Crouch, 2015: 187). 'Modest readjustments' that are 'cumulatively significant' (Crouch, 2015: 187) may thus emerge from the producers and consumers of heritage. Indeed, these roles are complicated and interwoven when viewed through the lens of affect. We need to be careful here however that the pernicious consequences of certain representational practices are not downplayed in the pursuit of what Crouch terms a 'gentler' politics of affect (2015: 187). The example of Angkor demonstrates that we must remain alert to the political, ethical and material implications of recurring image forms; visualities that - while embedded in complex subjectivities and affective responses - speak of a narrowing sense of what might constitute the 'heritage' of a site. 
As Terry Eagleton has affirmed, the aesthetic does not exist in a vacuum; it is concerned with 'how the world strikes the body on its sensory surfaces, of that which takes root in the gaze and the guts and that arises from our most banal, biological insertion into the world' (1990: 13). Any sense of the passive contemplation of mythic sites dissolves in this reading, with the 'messiness' of human engagements opening up the aesthetics of heritage to a more embodied conceptualisation. At the same time, the ethical and political implications of an explicit aestheticisation of the world cannot be overlooked. To this end, where Eagleton draws attention to banal insertions in the world at an individual level, I have suggested that the collectivities of mundane experience should be prioritised in theorisations of heritage. The cliché has provided one route into this debate - its tremulous qualities simultaneously fixing, multiplying and confusing the heritage object. Indeed, it is my suggestion that this moment of embodied confusion may in fact represent a critical juncture for heritage, being the space where - perhaps paradoxically - a more ethically and politically minded engagement with the past in the present can begin to take hold.

\section{Acknowledgments}

Earlier versions of this paper were presented at the Photographic History Research Centre Annual Conference, De Montfort University and Photography in (Con)text at University College London. I would like to thank discussants for helping to shape the direction of this work. I would also like to thank two anonymous reviewers, whose insightful comments helped sharpen some of the arguments put forward in this paper.

\section{Note on contributor}

Colin Sterling is a post-doctoral Research Associate at University College London. His current research investigates the implications of posthumanist thinking for cultural heritage. Prior to this, Colin was a Project Curator at the Royal Institute of British Architects and a Research Associate with the heritage consultancy Barker Langham. His PhD, which was awarded in 2015, examined the interrelationship of heritage and photography with specific reference to historic sites in Cyprus and Cambodia. He is currently completing a monograph on photography, heritage and affect to be published by Routledge.

Corrspondence to: Colin Philip Sterling, Institute of Archaeology, University College London, London, UK. Email: c.sterling@ucl.ac.uk

\section{Bibliography}

Albers, P. C. \& James, W. J. 1988. Travel Photography: A Methodological Approach. Annals of Tourism Research, 15: 134-158

Angkor Sunset Finder. 2013. About Sunsets in the Angkor Park. [online] [accessed 29 August 2016]. Available at: http://angkorsunsets.com/

Augé, M. 1995. Non-Places. [Trans John Howe]. London and New York: Verso

Barnett, A. 1990. Cambodia Will Never Disappear. New Left Review, 180: 101-125

Bell, D. A. 2003. Mythscapes: Memory, Mythology, and National Identity. British Journal of Sociology, 54(1): 63-81

Benjamin, W. 2007 [1968]. Illuminations. [Trans Harry Zohn]. New York: Schocken Books 
Bourdieu, P. 1990. Photography: A Middle-Brow Art. Stanford: Stanford University Press

Brett, D. 1996. The Construction of Heritage. Cork: Cork University Press

Burgin, V. ed. 1982. Thinking Photography. London: Macmillan Press

Butler, B. 2006. Heritage and the Present Past. In: C. Tilley, W. Keane, S. Kuchler, M. Rowlands and P. Spyer, eds. Handbook of Material Culture. London: Sage, pp. 463-479

Byrne, D. 2004. Chartering Heritage in Asia's Postmodern World. News in Conservation, 19(2): 1619

Byrne, D. 2008. Heritage as Social Action. In: G. Fairclough, R. Harrison, J.H. Jameson Jr., and J. Schofield, eds. The Heritage Reader. London \& New York: Routledge, pp. 149-173

Califano, C. 2005. Angkor Site Planning and Phnom Bakheng's Landscape. In: J. Clark, ed. Phnom Bakheng Workshop on Public Interpretation. Conference Proceedings. Cambodia: World Monuments Fund, pp. 100-5

Campbell, G. \& Smith, L. 2016. Keeping Critical Heritage Studies Critical: Why "PostHumanism" and the "New Materialism" Are Not So Critical. Unpublished conference paper given at the third Association of Critical Heritage Studies Conference, Montreal, Canada, June 2016. [online] [accessed 29 August 2016]. Available at: https://www.academia.edu/s/8a0187a64d/keeping-critical-heritage-studies-critical-why-posthumanism-and-the-new-materialism-are-not-so-critical

Chandler, D. 1993. A History of Cambodia. St Leonards: Allen \& Unwin

Choay, F. 2001 [1992]. The Invention of the Historic Monument. [Trans L. M. O'Connell]. Cambridge: Cambridge University Press

Cooper, N. 2001. France in Indochina: Colonial Encounters. Oxford \& New York: Berg

Crouch, D. \& Lübbren, N. 2003. Introduction. In: D. Crouch \& N. Lübbren, eds. Visual Culture and Tourism. Oxford \& New York: Berg

Crouch, D. 2015. Affect, Heritage, Feeling. In: E. Waterton \& S. Watson, eds. The Palgrave Handbook of Contemporary Heritage Research. Basingstoke: Palgrave Macmillan, pp. 177-190

de Certeau, M. 1984. The Practice of Everyday Life. Berkeley, Los Angeles, London: University of California Press

Di Giovine, M. 2009. The Heritage-Scape: UNESCO, World Heritage, and Tourism. Lanham, New York, Plymouth: Lexington Books

Duttlinger, C. 2008. Imaginary Encounters: Walter Benjamin and the Aura of Photography. Poetics Today, 29(1): 79-101

Eagleton, T. 1990. The Ideology of the Aesthetic. Oxford: Blackwell 
Edensor, T. 1998. Tourists at the Taj: Performance and Meaning at a Symbolic Site. London \& New York: Routledge

Edensor, T. 2014. The Multi-sensual Image and the Archaeological Gaze. Journal of Contemporary Archaeology, 1(1): 24-26

Falser, M. 2013. From Colonial Map to Visitor's Parcours: Tourist Guides and the Spatiotemporal Making of the Archaeological Park of Angkor. In: M. Falser \& M. Juneja, eds. Archaeologizing Heritage? Transcultural Entanglements Between Local Social Practices and Global Virtual Realities. Berlin: Springer, pp. 81-106.

Flusser, V. 2000 [1983]. Towards a Philosophy of Photography. London: Reaktion Books

Gregg, M. \& Seigworth, G. J. eds. 2010. The Affect Theory Reader. Durham and London: Duke University Press

Hall, S. 1999. Whose Heritage?: Un-settling "the heritage," re-imagining the post-nation. Third Text, 49: 3-13

Harrison, R. 2013. Heritage: Critical Approaches. London: Routledge

Harrison, R. 2015. Beyond "Natural" and "Cultural" Heritage: Toward an Ontological Politics of Heritage in the Age of the Anthropocene. Heritage \& Society, 8(1): 24-42

Hauser-Schäublin, B. ed. 2011. World Heritage Angkor and Beyond: Circumstances and Implications of Listings in Cambodia. Göttingen: Universitätsverlag Göttingen

Higham, C. 2001. The Civilization of Angkor. London: Weidenfeld and Nicolson

Hobsbawm, E. \& Ranger, T. eds. 1983. The Invention of Tradition. Cambridge: Cambridge University Press

Huyssen, A. 2010. Authentic Ruins: Products of Modernity. In: J. Hell \& A. Schönle, eds. Ruins of Modernity. Durham and London: Duke University Press, pp. 17-28

Jones, S. 2010. Negotiating Authentic Objects and Authentic Selves: Beyond the Deconstruction of Authenticity. Journal of Material Culture, 15: 181-203

Kennedy, H. G. 1867. Report of an Expedition Made into Southern Laos and Cambodia in the Early Part of the Year 1866. Journal of the Royal Geographical Society of London, 37: 298-328

Larsen, J. 2006. Geographies of Tourist Photography: Choreographies and Performances. In: J. Falkheimer \& A. Jansson, eds. Geographies of Communication: The Spatial Turn in Media Studies.

Gøteborg: Nordicom, pp. 241-257

Larsen, J. 2012. The Aspirational Tourist Photographer. Either/And. [online] [accessed 29 August 2016]. Available at: http://eitherand.org/reconsidering-amateur-photography/aspirationaltourist-photographer/

Lonely Planet. 2012. Cambodia. London: Lonely Planet 
Lorimer, H. 2005. Cultural geography: the busyness of being 'more-than-representational.' Progress in Human Geography, 29(1): 83-94

Lowenthal, D. 1985. The Past is a Foreign Country. Cambridge: Cambridge University Press

Malpas, J. 2008. New Media, Cultural Heritage, and the Sense of Place: Mapping the Conceptual Ground. International Journal of Heritage Studies, 15: 197-209

Massumi, B. 2015. Politics of Affect. Cambridge, UK; Malden, MA: Polity

Meades, J. 2012. Museum Without Walls. London: Unbound

Merleau-Ponty, M. 2004 [1948]. The World of Perception. London: Routledge

Miura, K. 2005. Conservation of a 'Living Heritage Site': A Contradiction in Terms? A Case Study of Angkor World Heritage Site. Conservation and Management of Archaeological Sites, 7(1): 3-18

Miura, K. 2012. Think Globally and Act Globally in Angkor World Heritage Site. World Heritage on the Ground: Ethnographic Perspectives. Max-Planch Institute for Social Anthropology, 11-12

October

Mouhot, H. 1966 [1864]. Henri Moubot's Diary. Travels in the Central Parts of Siam, Cambodia and Laos during the years 1858-61. Abridged and Edited with an Introduction by C. Pym. London, New York, Kuala Lumpur: Oxford University Press

Navaro-Yashin, Y. 2009. Affective spaces, melancholic objects: ruination and the production of anthropological knowledge. Journal of the Royal Anthropological Institute, 15: 1-18

Navaro-Yashin, Y. 2012. The Make-Believe Space: Affective Geography in a Postwar Polity. Durham and London: Duke University Press.

Nora, P. 1989. Between Memory and History: Les Lieux de Mémoire. Representations 26 (Spring): $7-24$

Norindr, P. 2006. The Fascination for Angkor Wat and the Ideology of the Visible. In: T. Winter \& L. C. Ollier, eds. Expressions of Cambodia: The Politics of Tradition, Identity and Change. London: Routledge, pp. 54-70

Pasternak, G. 2013. Photographic Histories, Actualities, Potentialities: Amateur Photography as Photographic Historiography. Either/And. [online] [accessed 29 August 2016]. Available at: http:// eitherand.org/reconsidering-amateur-photography/photographic-histories-actualitiespotentialities-/

Said, E. 1994. Culture and Imperialism. London: Vintage

Selby, M. 2010. People-Place-Past: The Visitor Experience of Cultural Heritage. In: S. Watson and E. Waterton, eds. Culture, Heritage and Representation: Perspectives on Visuality and the Past. Farnham: Ashgate, pp. 39-56 
Sitwell, O. 1984 [1939]. Escape With Me! An Oriental Sketchbook. Oxford and New York: Oxford University Press

Smith, L. 2006. Uses of Heritage. London: Routledge

Sontag, S. 2002 [1977]. On Photography. London: Penguin

Sterling, C. 2014. Review of 'The Semiotics of Heritage Tourism'. Papers from the Institute of Archaeology, 24(1): 1-4

Stewart, K. 2005. Cultural Poesis: The Generativity of Emergent. In: N. K. Denzin and Y. S. Lincoln, eds. Handbook of Qualitative Research. London: Sage, pp. 1015-30

Stylianou-Lambert, T. 2012. Tourists with Cameras: Reproducing or Producing? Annals of Tourism Research, 39(4): 1817-1838

Sun Kerya, C. 2005. Tourist Patterns at Phnom Bakheng. In: J. Clark, ed. Phnom Bakheng Workshop on Public Interpretation. Conference Proceedings. Cambodia: World Monuments Fund, pp. 138-146

Tilley, C. 1997. A Phenomenology of Landscape: Places, Paths and Monuments. London: Berg

Tolia-Kelly, D. 2006. Affect: An Ethnocentric Encounter? Area, 38(2): 213-217

Tolia-Kelly, D. P., Waterton, E. \& Watson, S. eds. 2017. Heritage, Affect and Emotion: Politics, Practices and Infrastructures. Abingdon, Oxon \& New York: Routledge

Trigg, D. 2012. The Memory of Place: A Phenomenology of the Uncanny. Athens, OH: University of Ohio Press

Urry, J. 2002. The Tourist Gaze. Second Edition. London: Sage

Waterton, E. \& Watson, S. 2013. Framing theory: towards a critical imagination in heritage studies. International Journal of Heritage Studies, 19(6): 546-561

Waterton, E. \& Watson, S. 2014. The Semiotics of Heritage Tourism. Bristol, Buffalo, Toronto: Channel View Publications

Waterton, E. 2010. Branding the past: The visual imagery of England's heritage. In: E. Waterton and S. Watson, eds. Culture, Heritage and Representation: Perspectives on Visuality and the Past.

Farnham: Ashgate, pp. 155-172

Watson, S. \& Waterton, E. eds. 2010. Culture, Heritage and Representation: Perspectives on Visuality and the Past. Farnham: Ashgate

Winter, T. 2006. Ruining the Dream? The Challenge of Tourism at Angkor, Cambodia. In: K. Meethan, A. Anderson \& S. Miles, eds. Tourism Consumption and Representation: Narratives of Place and Self. Wallingford: CABI, pp. 46-66

Winter, T. 2007. Post-conflict Heritage, Postcolonial Tourism: Culture, Politics and Development at Angkor. London \& New York: Routledge 
Winter, T. 2008. Post-conflict Heritage and Tourism in Cambodia: The Burden of Angkor. International Journal of Heritage Studies, 14(6): 524-539

Zembylas, M. 2006. Witnessing in the classroom: The ethics and politics of affect. Educational Theory, 56(3), 305-324

Zhu, Y. 2012. Performing Heritage: Rethinking Authenticity in Tourism. Annals of Tourism Research, 39(3), 1495-1513

Notes

i A plan of Angkor Wat was drawn by a Japanese pilgrim in the early $17^{\text {th }}$ century, and earlier written accounts of the temple are known, but Mouhot's were the first images to circulate widely

ii This is despite the presence of wooden walkways across the site, originally constructed for the filming of Jean-Jacques Annaud's 2004 film Two Brothers. 